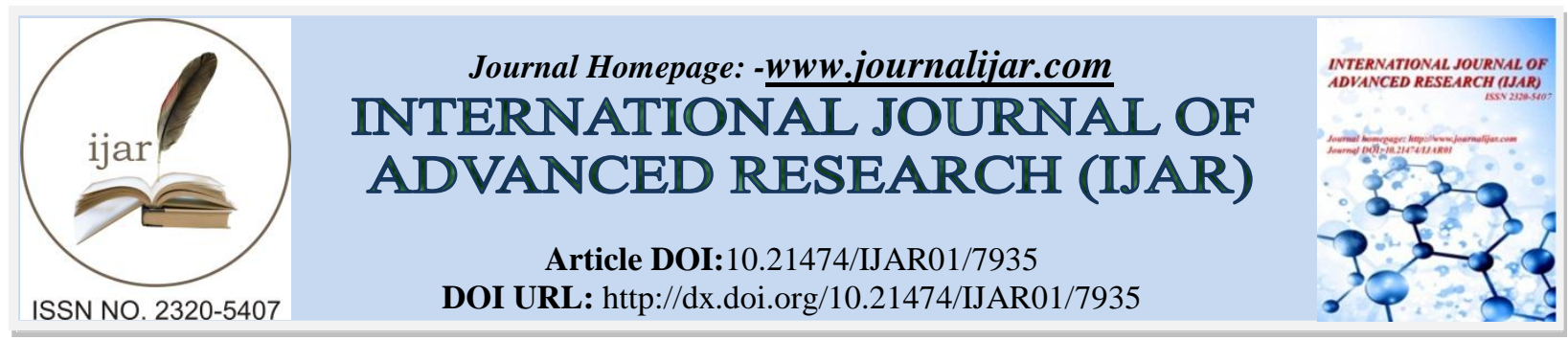

RESEARCH ARTICLE

\title{
PERSPECTIVES OF USAGE OF NATURAL ZEOLITE SATURATED WITH KILN GASSES OF CEMENT CLINKER.
}

\section{Teimuraz Kordzakhia ${ }^{1}$, Rajden Skhvitaridze ${ }^{2}$, Giorgi Tsintskaladze ${ }^{1}$, Irakli Giorgadze ${ }^{2}$, Shalva Verulava ${ }^{2}$} and Akaki Skhvitaridze ${ }^{2}$.

1. Iv.Javakhishvili Tbilisi State University; P.Melikishvili Institute of Physical and Organic Chemistry, 31 A.Politkovskaya str., 0186, Tbilisi, Georgia.

2. Scientific Center "NanoDugabi", Georgian Technical University, Tbilisi, Georgia.

\section{Manuscript Info}

..........................

Manuscript History

Received: 15 August 2018

Final Accepted: 17 September 2018

Published: October 2018

Keywords:-

zeolite, cement, kiln for clinker, technogenic gasses, adsorption, infrared spectroscopy.

\section{Abstract}

For the purpose of prevention of emission of $\mathbf{C O}_{2}, \mathbf{S O x}, \mathbf{N O x}$ in the atmosphere and proper global problems, such as "Thermal effect" and "acid rains", there has been offered sorbent trapping with zeolites cleaning of technogenic oxides coming out of the kiln of cement clinker and afterwards by grinding of these saturated sorbents and utilizing them as a mineral additive zeolite modifying of cement innovative BAT nanotechnology methods.

Copy Right, IJAR, 2018,. All rights reserved.

\section{Introduction:-}

Despite existing of lots of different means of neutralization of harmful components of gasses dissipated in the atmosphere (the main sources of which are energetic, chemical-metallurgical and cement enterprises) choosing of rational and effective cleaning methods is getting more and more actual. Because of becoming requirements stricter in relation to emission of stack gasses in the atmosphere [1,2], it is necessary to develop cleaning technologies of stack gasses. One of the perspective methods of cleaning of stack gasses is a sorption method - by using natural zeolites.

\section{Matter point of the problem}

Nowadays the "main source" of emission of stack gasses and their components, such as $\mathrm{CO}_{2}, \mathbf{S O x}, \mathbf{N O x}$, into the atmosphere, is a kiln of clinker in cement production.

Clinker raw charge contains on average $80 \%$ limestone - $\mathbf{C a C O}_{3}$. In case of using coal as fuel, as a result of burning $\mathrm{CO} / \mathrm{CO}_{2}, \mathrm{SO}_{2} / \mathrm{SO}_{3}$, and $\mathrm{NO} / \mathrm{NO}_{2}$ are moving to the stack gasses. Definitely: by the stack gasses of the clinker kiln

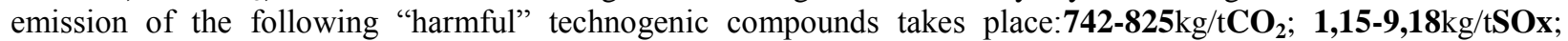

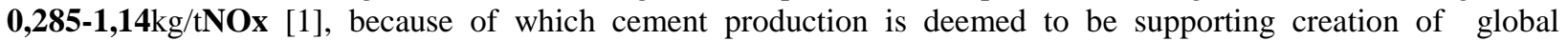
problems "hot-house effect"/ "acid rains". The share of cement production in the emission of $\mathbf{C O}_{2}$ in environment is deemed to be 6-8\% [2]. At the same time these emitted technogenic substances are modifying mixtures of structural composition of cement-concrete and are supporting intensive solidification process. They are participating in creating crystallohydrates of complex, needle fiber habit (hydro calcium carboalluminate $-\mathbf{C}_{3} \mathbf{A} \quad \mathbf{3 C a C O}_{3} \mathbf{3 1 H}_{2} \mathbf{O}$ ettringite- $\mathrm{C}_{3} \mathrm{~A} 3 \mathrm{CaSO}_{4} 31 \mathrm{H}_{2} \mathrm{O}$, thaumasite- $\mathrm{C}_{3} \mathrm{~S} \mathrm{SO}_{4} \mathbf{C O}_{3} 15 \mathrm{H}_{2} \mathrm{O}$ ) and self (nano)- reinforcement, in the decrease of anisotropicity of concrete strength [3]. 
In Georgia high-functional cement-concrete is in demand, satisfaction of which is hindered by fragility of its structure, less stability to bending loads, i.e. anisotropicity of mechanical strength.

Natural zeolites, which Georgia is rich of (their supply exceeds $300 \mathrm{mln} \mathrm{t}$ ), are characterized with macromolecular system, having well developed surface, activity of which is due to the molecular-sieve effect of micro and nanopores and also diffusion and sorption processes, have ability to take in technogenic compounds emitted during clinker burning $\mathrm{CO}_{2}$, SOx, NOx. These gasses are ecologically harmful, but joining with zeolite by sorption and after utilization of this modified zeolite in the composition of cement they become structural components of cementconcrete - nano-modifying compounds, because after mixing of cement they must form crystallohydrates of cement containing structural $\mathrm{CO}_{2}$, SOx, NOx.

Earlier in production of cement there was offered by us perspectives of using zeolites as pozzolanic mineral addition $[4,5]$. There have been worked up technologies of different contents. Among them is the technology, which envisages drying of zeolite before grinding it together with clinker using the heat of stack gasses of the clinker kiln [6]. If we create certain conditions in the drying process of zeolite by the stack gasses, zeolite might trap $\mathbf{C O}_{2}, \mathbf{S O x}$, NOx by adsorption and stack gasses will be cleaned from them.

\section{Experimental part}

In pilot conditions an experiment was conducted, for which zeolite containing clinoptilolite of fraction 5-10 mm was prepared. For identifying adsorbed oxides $\mathrm{CO}_{2}, \mathbf{S O x}, \mathbf{N O x}$ in the mentioned zeolite method of infrared spectroscopy was used. Infrared spectra were taken in far infrared and middle infrared bands on spectrophotometer „Agilent Technologies Cary 630 FTIR".

Probes were taken from the grid, which was placed in the pipe of the stack gas on the $7^{\text {th }}, 14^{\text {th }}, 21^{\text {st }}$ and $27^{\text {th }}$ day of working of the zeolitic filter. In the drawingbelow are given infrared spectra of these samples and initial zeolites.

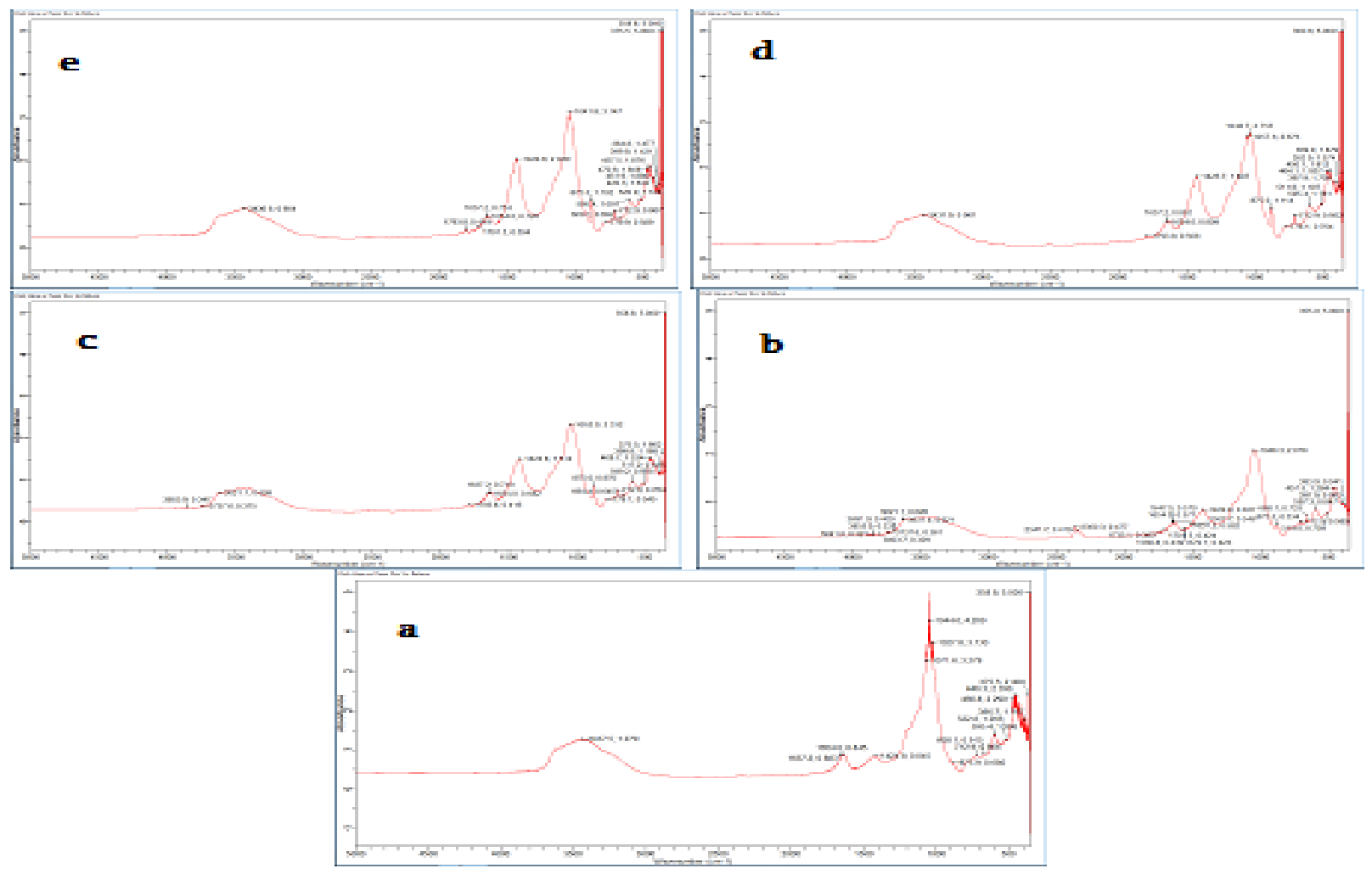

Drawing:

Infrared spectra of aluminosilicate carcass of the takenprobes from the initial (a) and zeolitic filters in far and middle infrared bands on the $7^{\text {th }}(\mathrm{b}), 14^{\text {th }}(\mathrm{c})$, on the $21^{\text {st }}(\mathrm{d})$ and $28^{\text {th }}$ day (e) of working. 
As it is seen from the drawing the spectrum of the initial sample fully corresponds to the data given in literature [7,8], accordingly these are bands of tetrahedral deformational vibration inside aluminosilicate at $466 \mathrm{~cm}^{-1}$ and valence vibration at $1044.6 \mathrm{~cm}^{-1}$, also bands of vibration between tetrahedrons accordingly are at 522.8, 595.4, $668.1,712.9 \mathrm{~cm}^{-1}$. Characteristic bands of natural minerals are: deformational of water at $1654.2 \mathrm{~cm}^{-1}$ and valence at $3437.5 \mathrm{~cm}^{-1}$ and vibration bandof adsorbed carbon-ions at $1424.8 \mathrm{~cm}^{-1}$. In infrared spectrum taken on the $7^{\text {th }}$ day and especially on the $14^{\text {th }}$ day the picture is changing -intensity of bands at $1424 \mathrm{~cm}^{-1}, 875$ and $712 \mathrm{~cm}^{-1}$, which correspond to $\mathrm{CO}_{3}^{-2}, \mathrm{NO}_{2}^{-}, \mathrm{NO}_{3}^{-}, \mathrm{SO}_{3}^{-2}$ and $\mathrm{SO}_{4}^{-2}$-ions accordingly [9,10]. Vibration frequencies of these ions are very close to each other and often their corresponding bands are overlapped. Also valence vibration band of $\mathrm{Si}-\mathrm{O}-\mathrm{Si}$ aluminosilicate at $1044 \mathrm{~cm}^{-1}$ coincides with vibration bands of $\mathrm{SO}_{4}^{-2}$ and $\mathrm{NO}_{2}$ ions [10], hence it is hard to fix absorbed ions exactly, though the general picture is clear. Intensity of bands of adsorbed ions in zeolitic filters from the clinker kiln is gradually increasing and reaches its maximum in the spectrum of the sample taken after the $28^{\text {th }}$ day (drawing).

In the laboratory conditions we conducted adsorption of $\mathrm{CO}_{2}, \mathrm{~N}_{2} \mathrm{O}$ and $\mathrm{SO}_{2}$ separatelyon zeolites. Infrared spectra of these samples confirmed the results of the experiments performed in the pilot conditions.

In the laboratory and pilot conditions from adsorptive zeolitic tuff of $\mathbf{C O}_{2}, \mathbf{S O x}, \mathbf{N O x}$ oxideswere prepared 6 samples, which in the amount of 20 mass \% were mixed with cement composition. For the purpose of comparing the prepared 6 samples of "modified" cement there were prepared initial without additive CEM I 52, 5 type and 20 mass \% cements containing unmodified and modified zeolites. Testing was carried out by EN 196-1 method, Results are represented in Table 1.

Table 1:-Testing results of plain cements of CEM I 52, 5 type 20 mass \% containing unmodified and modified zeolites

\begin{tabular}{|c|c|c|c|c|c|c|c|c|c|c|c|c|c|c|c|}
\hline \multirow{3}{*}{ \# } & \multicolumn{9}{|c|}{ Cement composition, mass $\%$} & $\mathrm{w} / \mathrm{c}$ & \multicolumn{5}{|c|}{ Physico-mechanical properties } \\
\hline & \multirow[t]{2}{*}{ Clinker } & \multirow[t]{2}{*}{ Plaster } & \multirow[t]{2}{*}{ Initial } & \multirow[t]{2}{*}{$\mathrm{CO}_{2}$} & \multirow[t]{2}{*}{$\mathrm{SO}_{\mathrm{X}}$} & \multirow[t]{2}{*}{$\mathrm{NO}_{\mathrm{X}}$} & \multirow[t]{2}{*}{$\begin{array}{l}\mathrm{CO}_{2+} \\
\mathrm{NO}_{\mathrm{X}}\end{array}$} & \multirow[t]{2}{*}{$\begin{array}{l}\mathrm{CO}_{2+} \\
\mathrm{SO}_{\mathrm{X}}\end{array}$} & \multirow{2}{*}{$\begin{array}{l}\mathrm{CO}_{2+} \\
\mathrm{SO}_{\mathrm{X}+} \\
\mathrm{NO}_{\mathrm{X}}\end{array}$} & \multirow[t]{2}{*}{$\%$} & \multicolumn{2}{|c|}{$\begin{array}{l}\text { Binding tems } \\
\text { hr-min }\end{array}$} & \multicolumn{3}{|c|}{$\begin{array}{l}\text { Strengthbending/compaction, } \\
\mathrm{mPa}\end{array}$} \\
\hline & & & & & & & & & & & Start & Finish & $\begin{array}{c}\text { Day } \\
2\end{array}$ & $\begin{array}{c}\text { Day } \\
7\end{array}$ & Day 28 \\
\hline 1 & 95 & 5 & - & - & - & - & - & - & - & 36.0 & $2-00$ & $3-05$ & 25.6 & 34.3 & $7.0 / 54.8$ \\
\hline 2 & 75 & 5 & 20 & - & - & - & - & - & - & 40.8 & $2-30$ & $3-10$ & 26.2 & 34.4 & $7.7 / 52.6$ \\
\hline 3 & 75 & 5 & - & 20 & - & - & - & - & - & 37.0 & $2-40$ & $3-40$ & 29.4 & 39.4 & $9.3 / 59.0$ \\
\hline 4 & 75 & 5 & - & - & 20 & - & - & - & - & 38.4 & $1-15$ & $2-20$ & 18.8 & 24.8 & $4.7 / 33.7$ \\
\hline 5 & 75 & 5 & - & - & - & 20 & - & - & - & 38.4 & $3-00$ & $4-10$ & 32.0 & 43.2 & $8.2 / 60.7$ \\
\hline 6 & 75 & 5 & - & - & - & - & 20 & - & - & 37.6 & $2-50$ & $4-40$ & 24.4 & 30.6 & $7.1 / 47.8$ \\
\hline 7 & 75 & 5 & - & - & - & - & - & 20 & - & 38.4 & $1-00$ & $2-35$ & 29.6 & 35.2 & $6.2 / 49.4$ \\
\hline 8 & 75 & 5 & - & - & - & - & - & - & 20 & 42.0 & $1-35$ & $2-40$ & 28.0 & 27.6 & $8.1 / 47.9$ \\
\hline
\end{tabular}

Initial cement under study was serial "HeidelbergCement Georgia" of type CEM I 52,5R. It was mixed with 20 mass $\%$ of initial natural zeolitic and adsorbed tuffs, by means of which it was turned into modified cement of CEM II type.

Mixing of the cement under study with $\mathbf{2 0}$ mass \% zeolitic tuff is increasing water demand by $4.80 \%$, slowing down the binding speed and is increasingcement strength (initial 2-7-day strength) by $\mathbf{0 , 5 0 - 2 , 3 0 \% , ~ a l s o ~ i s ~ i n c r e a s i n g ~} 28$ day strength under binding by $\mathbf{1 0} \%$ and decreasing 28-day strength under compaction by $4 \%$;

Mixing of the cement under study with 20 mass $\% \mathrm{CO}_{2}$ adsorbed zeolitic tuff is increasing its water demand only by $1 \%$, isslowing down the binding speed, is increasing the cement strength under compaction by $7,60-14,80 \%$ and under bending by $32,80 \%$ at all stages;

Mixing of the cement under study with 20 mass \% SOx adsorbed zeolitic tuff is increasing its water demand only by $2,40 \%$, is quickening the binding speed sharply, and is decreasing mechanical strength under bending/compaction by 26,50-38,50\%; 
Mixing of the cement under study with 20 mass $\%$ NOx is increasing its water demand only by $2,40 \%$, is slowing down the binding timesharply at all stages, at all stages-most sharply by10,70-25,00 is increasing strength on compactionby $17,14 \%$-strength on bending;

Mixing of the cement under study with 20 mass $\% \mathrm{CO}_{2}+\mathrm{NOx}$ adsorbed zeolitic tuff, only by $1,60 \%$ is increasing its water demand, is slowing down binding speed, by 12,70\%-is decreasing strength on compaction and by 1,40\% is increasing strength on bending;

Mixing of the cement under study with 20 mass $\% \mathrm{CO}_{2}+\mathrm{SOx}$ adsorbed zeolitic tuff, only by $2,40 \%$ is increasing its water demand, is increasing binding speed by 2 times, by $2,60-15,62 \%$ is increasing the initial strength and by $9,80 \%$ is decreasing 28 - day strength;

Mixing of the cement under study with 20 mass $\% \mathrm{CO}_{2}+\mathrm{SOx}+\mathrm{NOx}$ adsorbed zeolitic tuff, is sharply increasing by $6 \%$ as its water demand, as well as binding capacity,by $9,37 \%$ is increasing 2-day strength and $12,60 \%$ is decreasing 28-day strength;

Cements of CEM II type containing zeolitic tuffs adsorbed with $\mathrm{CO}_{2}$ and $\mathrm{NOx}$ are of the highest strength!

On all samples of studied cement was performed X-ray diffractometric analysis. Results are given in Table 2.

Table 2:-Results of X-ray structural analysis on the studied samples of cement

\begin{tabular}{|c|c|c|c|c|c|c|c|c|}
\hline \# & \multirow[t]{2}{*}{ Composition of cementmass $\%$} & \multicolumn{7}{|c|}{$\begin{array}{l}\text { diffraction peaks of compounds in cement stone revealed by X-ray structural } \\
\text { analysis } d=\AA\end{array}$} \\
\hline & & $\begin{array}{l}\text { Alite } \\
\mathrm{C}_{3} \mathrm{~S}\end{array}$ & $\begin{array}{l}\text { Portlandi } \\
\text { te } \\
\mathrm{CH}\end{array}$ & $\begin{array}{l}\text { Stratlingi } \\
\text { te } \\
\mathrm{C}_{2} \mathrm{ASH}_{8}\end{array}$ & $\begin{array}{l}\text { Ettringit } \\
\mathrm{e} \\
\mathrm{C}_{2} \mathrm{AS}_{3} \mathrm{H} \\
32\end{array}$ & $\begin{array}{l}\text { Taumasi } \\
\text { te } \\
\mathrm{C}_{3} \mathrm{SC}_{3} \mathrm{~S}_{3} \\
14,5 \mathrm{H}_{2} \mathrm{O}\end{array}$ & $\begin{array}{l}\text { Calcium } \\
\text { carbo- } \\
\text { aluminat } \\
\text { e } \\
\mathrm{C}_{3} \mathrm{ACaC} \\
\mathrm{O}_{3} \\
12 \mathrm{H}_{2} \mathrm{O}\end{array}$ & $\begin{array}{l}\text { Calciu } \\
\mathrm{m} \\
\text { nitrate } \\
\mathrm{Ca}\left(\mathrm{NO}_{3}\right. \\
)_{2}\end{array}$ \\
\hline 1 & 2 & 3 & 4 & 5 & 6 & 7 & 8 & 9 \\
\hline 1 & 95clinker+5gypsum & $\begin{array}{l}3,03 ; 2,9 \\
8 ; \\
2,75 ; 2,6 \\
1 ; \\
2,32 ; 2,0 \\
3 ; \\
2,06 ; 1,9 \\
3 ; 1,82 ;\end{array}$ & $\begin{array}{l}4,90 ; \\
3,11 ; \\
2,618 ; \\
1,80\end{array}$ & - & $\begin{array}{l}9,70 \\
5,60 \\
4,70 \\
2,75 \\
2,58 \\
2,18\end{array}$ & - & - & - \\
\hline 2 & 75clinker+5gypsum+20zeolite & $\begin{array}{l}3,03 \\
2,98 \\
2,76 \\
2,74 \\
2,61 \\
2,18\end{array}$ & $\begin{array}{l}4,90 \\
2,618\end{array}$ & $\begin{array}{l}12,5 ; \\
3,037 ; \\
2,613 ; \\
2,40\end{array}$ & $\begin{array}{l}9,70 ; \\
5,60 ; \\
4,70 ; \\
3,88 ; \\
2,75 ; \\
2,58 ; \\
2,16\end{array}$ & - & - & - \\
\hline 3 & $\begin{array}{l}\text { 75clinker+5gypsum+20zeolite } \\
+\mathrm{CO}_{2}\end{array}$ & $\begin{array}{l}3,03 ; \\
2,98 ; \\
2,76 ; \\
2,75 ; \\
2,61 ; \\
2,44 ; \\
2,40 ; \\
2,18 ; \\
1,98\end{array}$ & $\begin{array}{l}4,90 \\
3,10 \\
2,618\end{array}$ & $\begin{array}{l}12,3 ; \\
3,037 ; \\
2,79 ; \\
2,613 ; \\
2,404\end{array}$ & $\begin{array}{l}9,70 ; \\
5,61 ; \\
4,70 ; \\
3,88 ; \\
3,04 ; \\
2,75 ; \\
2,183\end{array}$ & - & $\begin{array}{l}3,97 ; \\
3,04 ; \\
2,86\end{array}$ & - \\
\hline 4 & 75clinker+5gypsum+20zeolite & 3,03 & 4,90; & 12,10 & 9,70 & 3,62 & - & - \\
\hline
\end{tabular}




\begin{tabular}{|c|c|c|c|c|c|c|c|c|}
\hline & $+\mathrm{SO}_{\mathrm{x}}$ & $\begin{array}{l}2,98 \\
2,75 \\
2,61 ; \\
2,31 \\
2,18 \\
2,09 \\
2,05 \\
1,92\end{array}$ & $\begin{array}{l}3,10 \\
2,618\end{array}$ & $3,037$. & $\begin{array}{l}5,61 ; \\
4,70 ; \\
3,89 ; \\
3,24 ; \\
2,75 \\
2,58 \\
2,18\end{array}$ & $\begin{array}{l}3,26 ; \\
2,98 ; \\
2,75 ; 2,1 \\
0 .\end{array}$ & & \\
\hline 5 & $\begin{array}{l}\text { 75clinker+5gypsum+20zeolite } \\
+\mathrm{NO}_{\mathrm{x}}\end{array}$ & $\begin{array}{l}3,03 \\
2,08 \\
2,31 \\
2,18 \\
2,15\end{array}$ & $\begin{array}{l}4,90 \\
3,10 \\
2,618\end{array}$ & $\begin{array}{l}12,20 \\
4,28 \\
3,037\end{array}$ & $\begin{array}{l}9,70 ; \\
5,61 ; \\
4,71 ; \\
3,88 ; \\
3,23 ; \\
2,77 ; \\
2,22\end{array}$ & - & - & $\begin{array}{l}2,45 \\
2,18\end{array}$ \\
\hline 6 & $\begin{array}{l}\text { 75clinker+5gypsum+20zeolite } \\
+\mathrm{CO}_{2} / \mathrm{NO}_{\mathrm{x}}\end{array}$ & $\begin{array}{l}3,03 \\
2,98 \\
2,76 \\
2,75 \\
2,61 \\
2,03\end{array}$ & $\begin{array}{l}4,90 \\
3,10 \\
2,618\end{array}$ & $\begin{array}{l}12,20 \\
3,037 \\
2,40\end{array}$ & $\begin{array}{l}9,70 ; \\
5,61 ; \\
4,71 ; \\
3,88 ; \\
3,17 ; \\
2,75 ; \\
2,57 ; \\
2,183 .\end{array}$ & $\begin{array}{l}4,88 \\
3,18 \\
2,98 \\
2,75 \\
2,18\end{array}$ & - & 2,18 \\
\hline 7 & $\begin{array}{l}\text { 75clinker+5gypsum+20zeolite } \\
+\mathrm{CO}_{2} / \mathrm{SO}_{\mathrm{x}}\end{array}$ & $\begin{array}{l}3,03 \\
2,98 \\
2,76 \\
2,75 \\
2,61 \\
2,18\end{array}$ & $\begin{array}{l}4,90 \\
3,10 \\
2,618\end{array}$ & $\begin{array}{l}12,60 \\
3,037\end{array}$ & $\begin{array}{l}9,7 ; \\
5,60 ; \\
4,70 ; \\
3,88 ; \\
3,46 ; \\
3,21 ; \\
2,83\end{array}$ & $\begin{array}{l}5,53 \\
3,42 \\
2,98 \\
2,75 \\
2,59 \\
2,18\end{array}$ & - & - \\
\hline 8 & $\begin{array}{l}\text { 75clinker+5gypsum+20zeolite } \\
+\mathrm{CO}_{2} / \mathrm{NO}_{\mathrm{x}} / \mathrm{SO}_{\mathrm{x}}\end{array}$ & $\begin{array}{l}3,03 \\
2,98 \\
2,76 \\
2,75 \\
2,61 \\
2,32 \\
2,03 \\
1,76\end{array}$ & $\begin{array}{l}4,90 \\
3,10 \\
2,618\end{array}$ & $\begin{array}{l}12,47 \\
3,037 \\
2,40\end{array}$ & $\begin{array}{l}9,75 ; \\
5,63 ; \\
5,58 \\
4,70 ; \\
3,69 \\
3,46 ; \\
3,23 ; \\
2,76 ; \\
2,70 ; \\
2,56 ; \\
1,75\end{array}$ & $\begin{array}{l}3,62 \\
3,42 \\
2,98 \\
2,56 \\
2,21 \\
2,18 \\
2,15\end{array}$ & $\begin{array}{l}3,04 \\
2,86\end{array}$ & $\begin{array}{l}2,56 \\
2,18\end{array}$ \\
\hline
\end{tabular}

Apart from the first sample all the other samples of cement alongside with Alite, Portlandite, Ettringite must contain mineral stratlingite $\mathbf{C}_{2} \mathbf{A S H}_{8}$, which is caused because of mixing and existing of zeolitic tuffs in cement;

№3 sample of cement unlike others contains calcium carbo aluminate $\mathbf{C}_{3} \mathbf{A C a C O}_{3} \mathbf{1 2 H}_{2} \mathrm{O}$, which can be caused by mixing in cement zeolitic tuff adsorbed with $\mathrm{CO}_{2}$;

№5 unlike the rest of cement samples contains Calcium nitrate $\mathrm{Ca}\left(\mathrm{NO}_{3}\right)_{2}$, which might have been caused by mixing in cement zeolitic tuff adsorbed with NOx.

\section{Conclusion:-}

The performed work enables us to solve such global ecological problems as "thermal effect" and "acid rains" in the atmosphere by using zeolitic sorbents. Also by grinding such saturated sorbents and utilizing them as a mineral additive and further by zeolitic modifying of cement we can get cement-concrete of high strength 


\section{Acknowledgement:-}

The work was prepared with the support of the Ministry of Education and Science of Georgia and Shota Rustaveli National Science Foundation. Grant № AR 216800.

\section{Bibliography:-}

1. European Commission. Integrated Pollution Prevention and Control. Reference Document on Best Available Techniques (BAT) in the Cement and Magnesium Oxide Manufacturing industries. May 2010. http://eippecb.jrc.ec.europa.eu;

2. European Commission Council Directive 96/61/EC of 24 September 1996 concerning integrated pollution prevention and control. http://www.ifc.org;

3. G. Tsintskaladze, R. Skhvitaridze, B. Keshelava, V. Tsitsishvili, T. Kordzakhia and others"Clinoptilolite Modified by Sulfur Oxides, asan Additive in Cements". "Georgian Engineering News"(GEN), N2, v. 54,2010, p. $109-111$

4. R. Skhvitaridze, V. Tsitsishvili, B.Keshelava, G. Tsintskaladze"The Use of Natural Zeolites of Georgia as Additives of Building Materials".// Science and Technology N1(715), Tbilisi, 2014, pg. 98 - 102.

5. R.Skhvitaridze, I.Giorgadze, S.Verulava, E.Shapakidze, I.Gejadze, G.Tsintskaladze, T.Kordzakhia. "Scientific Principles and Practice in the Use of Natural Mineral and Resources in the Georgian Cement Industry". J. "CEMENT INTERNATIONAL", 2018, \#2, v.16, p.50-57.

6. Patent on invention AP 201814402 A. "Mode of Cement Producing". Inventors: R. Skhvitaridze, T. Kordzakhia, G. Tsintskaladze, I. Giorgadze, Sh. Verulava, A.Skhvitaridze, G. Kavtiashvili, published: Bulletin \#9 (493) 2018.05.10

7. Flanigen E., Khatami H., Szymanski H. Infrared structural studies of zeolites frameworks. Molecular Sieve Zeolites. Americ. Chem. Soc, 1970, TableV, p.460-488

8. V. Tsitsishvili., G.Tsintskaladze, P, Charkviani. Effect of Heat Treatment on IR spectra of Some Synthetic and Natural Zeolites in the Range of Oscillation Frequencies of a Carcass, Reports of Academy of Sciences of SSSR, 1983, т.273, №6, c.1434-1439.

9. Nakamoto K. Infrared Spectra of Nonorganic and Coordination Compounds, М.:Mир, 1966, 411c.

10. Gordon, R. Ford. Guide of Chemist / -M.: «Мир», 1976, 541c. 